Syntax Fusion : Jurnal Nasional Indonesia

p-ISSN: -

e-ISSN : 2775-4440

Vol. 1, No. 1, Oktober 2020

\title{
PENGARUH HAFALAN AL-QURAN TERHADAP MOTIVASI BELAJAR SISWA DALAM PEMBELAJARAN PENDIDIKAN AGAMA ISLAM DI MADRASAH TSANAWIYAH AL-FIRDAUS CIPATAT BANDUNG
}

\author{
Linda Siti Nurhayati dan Rifqi Fauzan Sholeh \\ STAI Persis Bandung \\ Email: lindasitinurhayati@gmail.com dan rifqifauzan121096@gmail.com
}

\begin{abstract}
Abstrak
Usaha-usaha untuk menghafal Al-Quran oleh sebagian umat islam terus berlanjut dan hal ini merupakan salah satu upaya untuk menjaga dan memelihara kemurnian Al-Qur'an. Penelitian ini memiliki tujuan untuk mengetahui sejauh mana Hafalan Al-Qur'an juz 30, 1 dan 2 siswa MTs Al-Firdaus. Untuk mengetahui sejauh mana motivasi siswa MTs Al-Firdaus dalam KBM. Untuk mengetahui bagaimana pengaruh hafalan Al-Qur'an terhadap motivasi belajar siswa dalam KBM.

Metode yang digunakan dalam penelitian ini adalah metode survei dengan pendekatan korelasional. Pengaruh hafalan Al-Quran terhadap motivasi belajar siswa Mts Al-Firdaus Cipatat-Bandung Barat pada mata pelajaran Pendidikan Agama Islam sebesar 13,69\%, dan sisanya 86,31\% dipengaruhi oleh faktor lain.

Nilai rata-rata siswa/siswi MTs Al-Firdaus Cipatat-Bandung Barat dalam bidang studi hafalan Al-Quran adalah 87,02. Realitas motivasi belajar siswa pada mata pelajaran Pendidikan Agama Islam menunjukkan kwalifikasi cukup. Hal ini ditunjukkan oleh hasil rata perhitungan statistik mencapai 3,29 dan angka tersebut berada pad interval 2,50 - 3,50. Setelah berdasarkan hasil analisis data, maka dapat disimpulkan bahwa pengaruh hafalan Al-Quran terhadap motivasi belajar siswa Mts Al-Firdaus Cipatat - Bandung Barat pada mata pelajaran Pendidikan Agama Islam sebesar 13,69\%, dan sisanya 86,31\% dipengaruhi oleh faktor lain.
\end{abstract}

Kata Kunci: Hafalan Al-Quran, Motivasi Belajar

\section{Pendahuluan}

Pendahuluan harus berisi (secara berurutan) latar belakang umum, kajian literatur terdahulu (state of the art) sebagai dasar pernyataan kebaruan ilmiah dari artikel, pernyataan kebaruan ilmiah, dan permasalahan penelitian atau hipotesis. Di bagian akhir pendahuluan harus dituliskan tujuan kajian artikel tersebut. Di dalam format artikel ilmiah tidak diperkenankan adanya tinjauan pustaka sebagaimana di laporan penelitian, tetapi 
diwujudkan dalam bentuk kajian literatur terdahulu (state of the art) untuk menunjukkan kebaruan ilmiah artikel tersebut.

Al-Qur'an dan hadits merupakan dua sumber ajaran islam dan pedoman hidup bagi umat islam. Keduanya mengajarkan prinsip-prinsip dan tata aturan kehidupan yang harus diajarkan oleh umatnya, tidak hanya terkait dengan tata hubungan manusia dengan Rabbnya (Hablun minalloh) tetapi juga tata aturan dalam kehidupan dengan sesama manusia (Hablun minannas).

Al-Qur'an sebagaimana yang dikutip oleh Dr. H. Abdul Madjid Khon, M.Ag dalam bukunya praktikum Qira'at adalah kalam Allah yang mengandung mukjizat diturunkan kepada penghulu para nabi dan rasul (yaitu muhammad SAW) melalui malaikat jibril yang tertulis pada mushaf, yang diriwayatkan kepada kita secara mutawatir, dinilai ibadah membacanya, yang dimulai dari surat Al- Fatihah dan diakhiri dengan surat An-nas.

Usaha yang dilakukan oleh lembaga pendidikan MTs Al-Firdaus Cipatat Bandung adalah sebagai salah satu lembaga pendidikan yang memadukan kurikulum Kemenag dan kurikulum kepesantrenan memiliki tujuan yang sangat mulia. Diantaranya mempersiapakan dan mencetak generasi yang Tahfid Al-Qur'an dimana setiap lulusannya dapat menguasai Al-Qur'an kurang lebih 5 Juz.

Berdasarkan pengamatan pada saat pembagian buku laporan pendidikan di Madrasah Tsanawiyah (MTs) Al-Firdaus Cipatat-Bandung, ternyata siswa yang memiliki prestasi hafalan Al-Quran paling tinggi bahkan melebihi hafalan kakak kelasnya sendiri dia juga mendapatkan nilai yang tinggi pula untuk mata pelajaran yang lainnya.

Dari pengamatan tersebut, disimpulkan bahwa siswa/siswi yang memiliki prestasi hafalan Al-Quran yang tinggi dia pun mendapatkan nilai yang tinggi bagi mata pelajaran lainnya. Sehingga diperkirakan bahwa siswa/siswi yang prestasi hafalan Al-Qurannya tinggi, akan mendorong/memotivasi untuk giat belajar.

Masalah yang akan diteliti perlu dirumuskan secara rinci dan terbatas, sebuah masalah yang dirumuskan terlalu umum dan luas tidak akan mendapatkan penyelesaian yang mendalam dalam sebuah penelitian, oleh karena itu masalah perlu memenuhi perumusan yang terbatas. (Surakhma, 1994 : 36). Oleh karena itu penulis perlu merumuskan masalah dalam bentuk pertanyaan-pertanyaan untuk membatasi dan mendalami penelitian ini, antara lain: (1) Bagaimanakah Hafalan Al-Qur'an juz 30, 1, 2 siswa MTs Al-Firdaus? (2) Bagaimana motivasi belajar siswa MTs Al-firdaus? (3) Bagaimana pengaruh hafalan Al-Qur'an terhadap motivasi belajar siswa MTs Al-Firdaus dalam PBM?

Maka penelitian ini memiliki tujuan sebagai berikut ini: (1) Untuk mengetahui sejauh mana Hafalan Al-Qur'an juz 30, 1 dan 2 siswa MTs Al-Firdaus. (2) Untuk mengetahui sejauh mana motivasi siswa MTs Al-Firdaus dalam KBM. (3) Untuk mengetahui bagaimana pengaruh hafalan Al-Qur'an terhadap motivasi belajar siswa dalam KBM. 


\section{Metode Penelitian}

metode penelitian yang digunakan dalam pemecahan permasalahan termasuk metode analisis. Keterangan gambar diletakkan menjadi bagian dari judul gambar (figure caption) bukan menjadi bagian dari gambar. Metode-metode yang digunakan dalam penyelesaian penelitian dituliskan di bagian ini.

\section{Hasil dan Pembahasan}

1. Analisis Hafalan Al-Qur'an di Madrasah Al-Firdaus Cipatat Bandung

Hafalan Al-qur'an diambil dari daftar nilai siswa pada buku daftar nilai, prestasi belajar yang diambil oleh penulis adalah nilai raport siswa pada semester genap tahun Ajaran 2013/2014 sebagai berikut:

\begin{tabular}{|c|c|c|}
\hline No & Kelas & Nilai Hafalan Al-Quran \\
\hline 1 & 9 & 88 \\
\hline 2 & 9 & 90 \\
\hline 3 & 9 & 86 \\
\hline 4 & 9 & 98 \\
\hline 5 & 9 & 95 \\
\hline 6 & 9 & 80 \\
\hline 7 & $8 \mathrm{a}$ & 80 \\
\hline 8 & $8 \mathrm{a}$ & 80 \\
\hline 9 & $8 \mathrm{a}$ & 90 \\
\hline 10 & $8 \mathrm{a}$ & 80 \\
\hline 11 & $8 a$ & 90 \\
\hline 12 & $8 a$ & 80 \\
\hline 13 & $8 \mathrm{a}$ & 90 \\
\hline 14 & $8 \mathrm{a}$ & 100 \\
\hline 15 & $8 \mathrm{a}$ & 90 \\
\hline 16 & $8 a$ & 90 \\
\hline 17 & $8 \mathrm{a}$ & 90 \\
\hline 18 & $8 b$ & 89 \\
\hline 19 & $8 b$ & 89 \\
\hline 20 & $8 b$ & 100 \\
\hline 21 & $8 b$ & 89 \\
\hline 22 & $8 b$ & 90 \\
\hline 23 & $8 b$ & 90 \\
\hline 24 & $8 b$ & 89 \\
\hline 25 & $7 a$ & 95 \\
\hline 26 & $7 \mathrm{a}$ & 80 \\
\hline 27 & $7 a$ & 80 \\
\hline 28 & $7 \mathrm{a}$ & 95 \\
\hline 29 & $7 \mathrm{a}$ & 80 \\
\hline
\end{tabular}




\begin{tabular}{|c|c|c|}
\hline 30 & $7 \mathrm{a}$ & 80 \\
\hline 31 & $7 \mathrm{a}$ & 80 \\
\hline 32 & $7 \mathrm{a}$ & 90 \\
\hline 33 & $7 \mathrm{a}$ & 95 \\
\hline 34 & $7 \mathrm{~b}$ & 85 \\
\hline 35 & $7 \mathrm{~b}$ & 85 \\
\hline 36 & $7 \mathrm{~b}$ & 85 \\
\hline 37 & $7 \mathrm{~b}$ & 85 \\
\hline 38 & $7 \mathrm{~b}$ & 75 \\
\hline 39 & $7 \mathrm{~b}$ & 80 \\
\hline 40 & $7 \mathrm{~b}$ & 80 \\
\hline 41 & $7 \mathrm{~b}$ & 80 \\
\hline 42 & $7 \mathrm{~b}$ & 89 \\
\hline 43 & $7 \mathrm{~b}$ & 90 \\
\hline & & 3742 \\
\hline
\end{tabular}

Tabel 3.5 Daftar nilai siswa

Jumlah nilai keseluruhan bidang studi hafalan Al-Quran siswa/siswi MTs AlFirdaus Cipatat Bandung Barat adalah 3742. Setelah jumlah nilai 3742 dibagi dengan jumlah responden yang berjumlah 43 orang, maka nilai rata-rata siswa/siswi MTs AlFirdaus Cipatat-Bandung Barat dalam bidang studi hafalan Al-Quran adalah 87,02. Dengan demikian, nilai rata-rata prestasi belajar siswa dalam bidang studi hafalan AlQuran di MTs Al-Firdaus Cipatat-Bandung Barat adalah baik sekali. Hal itu bila dikaitkan dengan Kriteria Ketuntasan Minimal (KKM) pada mata pelajaran hafalan Al-Quran adalah 70, maka semua siswa dapat dikatakan telah memenuhi kriteria ketuntasan minimal.

\section{Analisis Motivasi Belajar Siswa (variabel Y)}

Untuk mendapatkan data tentang motivasi belajar siswa di Madrasah Tsanawiyah Al-Firdaus maka penulis menyebarkan angket kepada 43 siswa yang telah ditetapkan menjadi responden dalam penelitian ini. Secara kumulatif, angket yang disebarkan terdidri dari sepuluh pertanyaan yang berhubungan dengan motivasi belajar.

Nilai yang diperoleh dari hasil angket motivasi belajar, dapat ditabulasikan pada tabel sebagai berikut:

\begin{tabular}{|c|c|c|c|c|c|c|c|c|c|c|c|}
\hline \multirow{2}{*}{ Siswa/i } & \multicolumn{10}{|c|}{ Item soal } \\
\cline { 2 - 14 } & 1 & 2 & 3 & 4 & 5 & 6 & 7 & 8 & 9 & 10 & Skor \\
\hline 1 & 4 & 2 & 4 & 4 & 3 & 2 & 2 & 4 & 4 & 3 & 32 \\
\hline 2 & 3 & 4 & 4 & 4 & 2 & 4 & 2 & 4 & 4 & 2 & 33 \\
\hline 3 & 4 & 2 & 3 & 4 & 4 & 2 & 2 & 4 & 4 & 3 & 31 \\
\hline 4 & 4 & 4 & 1 & 4 & 1 & 2 & 2 & 4 & 4 & 4 & 29 \\
\hline 5 & 3 & 3 & 2 & 4 & 4 & 2 & 2 & 4 & 4 & 3 & 30 \\
\hline
\end{tabular}




\begin{tabular}{|c|c|c|c|c|c|c|c|c|c|c|c|}
\hline 6 & 3 & 3 & 4 & 4 & 1 & 3 & 2 & 4 & 4 & 3 & 30 \\
\hline 7 & 4 & 4 & 2 & 4 & 1 & 4 & 2 & 4 & 4 & 4 & 32 \\
\hline 8 & 2 & 4 & 1 & 4 & 1 & 2 & 2 & 4 & 4 & 3 & 26 \\
\hline 9 & 2 & 3 & 3 & 4 & 4 & 4 & 2 & 4 & 4 & 4 & 34 \\
\hline 10 & 4 & 3 & 4 & 4 & 4 & 2 & 2 & 4 & 4 & 3 & 33 \\
\hline 11 & 4 & 4 & 4 & 4 & 4 & 2 & 2 & 4 & 4 & 2 & 33 \\
\hline 12 & 3 & 3 & 2 & 4 & 4 & 2 & 2 & 4 & 4 & 2 & 29 \\
\hline 13 & 4 & 3 & 1 & 4 & 3 & 2 & 4 & 4 & 4 & 2 & 30 \\
\hline 14 & 4 & 4 & 2 & 4 & 4 & 4 & 4 & 4 & 4 & 4 & 37 \\
\hline 15 & 4 & 4 & 1 & 4 & 2 & 2 & 2 & 4 & 4 & 4 & 30 \\
\hline 16 & 4 & 4 & 4 & 4 & 4 & 4 & 2 & 4 & 4 & 2 & 35 \\
\hline 17 & 2 & 4 & 2 & 4 & 4 & 2 & 2 & 4 & 4 & 3 & 30 \\
\hline 18 & 4 & 4 & 4 & 4 & 4 & 2 & 2 & 4 & 1 & 3 & 31 \\
\hline 19 & 4 & 4 & 3 & 4 & 4 & 2 & 4 & 4 & 4 & 3 & 35 \\
\hline 20 & 4 & 4 & 2 & 4 & 4 & 4 & 4 & 4 & 4 & 3 & 35 \\
\hline 21 & 4 & 3 & 3 & 4 & 4 & 2 & 4 & 4 & 4 & 3 & 34 \\
\hline 22 & 4 & 4 & 4 & 4 & 4 & 4 & 2 & 4 & 4 & 4 & 35 \\
\hline 23 & 4 & 3 & 4 & 4 & 3 & 2 & 4 & 4 & 4 & 4 & 33 \\
\hline 24 & 2 & 4 & 4 & 4 & 4 & 4 & 2 & 4 & 4 & 3 & 33 \\
\hline 25 & 4 & 4 & 1 & 4 & 2 & 2 & 4 & 4 & 4 & 3 & 31 \\
\hline 26 & 4 & 3 & 2 & 4 & 4 & 2 & 3 & 4 & 4 & 3 & 32 \\
\hline 27 & 2 & 4 & 2 & 4 & 4 & 2 & 1 & 4 & 4 & 3 & 29 \\
\hline 28 & 4 & 3 & 2 & 4 & 4 & 2 & 3 & 4 & 4 & 3 & 32 \\
\hline 29 & 3 & 3 & 3 & 4 & 1 & 4 & 2 & 4 & 4 & 4 & 29 \\
\hline 30 & 2 & 3 & 1 & 4 & 1 & 2 & 4 & 4 & 4 & 4 & 26 \\
\hline 31 & 4 & 4 & 1 & 4 & 1 & 2 & 2 & 4 & 4 & 4 & 27 \\
\hline 32 & 4 & 3 & 4 & 4 & 1 & 2 & 2 & 4 & 4 & 2 & 30 \\
\hline 33 & 2 & 3 & 1 & 4 & 4 & 2 & 4 & 4 & 4 & 2 & 30 \\
\hline 34 & 4 & 4 & 4 & 4 & 4 & 4 & 4 & 4 & 4 & 3 & 37 \\
\hline 35 & 4 & 3 & 4 & 4 & 4 & 2 & 4 & 4 & 4 & 3 & 36 \\
\hline 36 & 2 & 3 & 2 & 4 & 1 & 2 & 2 & 4 & 4 & 3 & 27 \\
\hline 37 & 2 & 3 & 2 & 4 & 1 & 2 & 2 & 4 & 4 & 4 & 25 \\
\hline 38 & 2 & 3 & 3 & 4 & 4 & 2 & 2 & 4 & 4 & 3 & 30 \\
\hline 39 & 2 & 3 & 3 & 4 & 1 & 2 & 2 & 4 & 4 & 3 & 27 \\
\hline 40 & 2 & 4 & 3 & 4 & 4 & 2 & 4 & 4 & 4 & 3 & 34 \\
\hline 41 & 4 & 4 & 4 & 4 & 4 & 2 & 2 & 4 & 4 & 2 & 33 \\
\hline 42 & 2 & 3 & 4 & 4 & 4 & 2 & 2 & 4 & 4 & 4 & 32 \\
\hline 43 & 4 & 3 & 3 & 4 & 4 & 2 & 2 & 4 & 4 & 4 & 32 \\
\hline$\sum$ & 141 & 147 & 117 & 172 & 130 & 107 & 111 & 172 & 169 & 83 & 1349 \\
\hline
\end{tabular}

Tabel 3.6 Tabulasi variabel Y 
Berdasarkan skor tabel diatas, selanjutnya dapat dihitung mengenai kriteria penilaian perindikator variabel motivasi belajar (variabel Y) atas jawaban responden yang berjumlah 43 dengan pengelolaan datanya sebagaimana penulis tuangkan pada tabel berikut ini:

Kriteria Penilaian Perindikator Motivasi Belajar Siswa (Variabel Y)

\begin{tabular}{|c|c|c|c|c|c|c|}
\hline No & Pertanyaan & $\begin{array}{l}\text { Alternatif } \\
\text { jawaban }\end{array}$ & $\mathrm{N}$ & $\mathrm{F}$ & $\begin{array}{l}\text { Skor } \\
(\mathrm{fxn})\end{array}$ & $\begin{array}{l}\text { Rata- } \\
\text { rata } \\
\sum \frac{f n}{r}\end{array}$ \\
\hline 1. & $\begin{array}{l}\text { Apakah setiap hari anda } \\
\text { menghapal Al-Qur'an } \\
\text { kurang lebih selama satu } \\
\text { jam }\end{array}$ & $\begin{array}{l}\text { Sering } \\
\text { Kadang } \\
\text { Kadang } \\
\text { Jarang } \\
\text { Tidak pernah }\end{array}$ & $\begin{array}{l}4 \\
3 \\
2 \\
1\end{array}$ & $\begin{array}{l}25 \\
5 \\
13 \\
0\end{array}$ & $\begin{array}{l}100 \\
15 \\
26 \\
0\end{array}$ & 3,3 \\
\hline 2. & $\begin{array}{l}\text { Apakah dalam satu hari } \\
\text { anda tidak sama sekali } \\
\text { meluangkanwaktu untuk } \\
\text { belajar }\end{array}$ & $\begin{array}{l}\text { Sering } \\
\text { Kadang } \\
\text { Kadang } \\
\text { Jarang } \\
\text { Tidak pernah }\end{array}$ & $\begin{array}{l}1 \\
2 \\
3 \\
4\end{array}$ & $\begin{array}{l}0 \\
2 \\
21 \\
20\end{array}$ & $\begin{array}{l}0 \\
4 \\
63 \\
80\end{array}$ & 3,4 \\
\hline \multicolumn{6}{|c|}{ Jumlah rata-rata } & 3,35 \\
\hline
\end{tabular}

Tabel 3.7 Indikator Motivasi belajar PAI mengenai durasi kegiatan

Nilai 3,35 berada di interval 2,50 - 3,50 dengan kriteria cukup, ini berarti kemampuan menggunakan waktu untuk melakukan kegitan hafalan Al-Qur'an oleh siswa madrasah Tsanawiyah Al-Firdaus berdasarkan skala kualifikasi berkatagori cukup.

\begin{tabular}{|c|c|c|c|c|c|c|}
\hline No & Pertanyaan & Alternatif jawaban & $\mathrm{N}$ & $\mathrm{F}$ & $\begin{array}{l}\text { Skor } \\
(\mathrm{fxn})\end{array}$ & $\begin{array}{l}\text { Rata-rata } \\
\qquad \sum \frac{f n}{r}\end{array}$ \\
\hline 1. & $\begin{array}{c}\text { Dalam satu minggu } \\
\text { apakah setiap hari anda } \\
\text { meluangkan waktu untuk } \\
\text { belajar di rumah. }\end{array}$ & $\begin{array}{c}\text { Sering } \\
\text { Kadang - Kadang } \\
\text { Jarang } \\
\text { Tidak pernah }\end{array}$ & $\begin{array}{l}4 \\
3 \\
2 \\
1\end{array}$ & $\begin{array}{c}16 \\
8 \\
11 \\
8\end{array}$ & $\begin{array}{c}64 \\
24 \\
22 \\
8\end{array}$ & 2,74 \\
\hline 2. & $\begin{array}{l}\text { Dalam satu minggu } \\
\text { apakah anda sekolah } \\
\text { setiap hari. }\end{array}$ & $\begin{array}{c}\text { Sering } \\
\text { Kadang - Kadang } \\
\text { Jarang } \\
\text { Tidak pernah }\end{array}$ & $\begin{array}{l}1 \\
2 \\
3 \\
4\end{array}$ & $\begin{array}{c}43 \\
0 \\
0 \\
0\end{array}$ & $\begin{array}{c}172 \\
0 \\
0 \\
0\end{array}$ & 4,0 \\
\hline \multicolumn{6}{|c|}{ Jumlah rata-rata } & 3,36 \\
\hline
\end{tabular}

Tabel 3.8 Indikator Motivasi belajar PAI mengenai Frequensi Kegiatan

Berdasarkan tabel diatas diperoleh nilai 3,35 berada di interval 2,50 -3,50 dengan kriteria cukup, ini berarti kemampuan berapa seringnya kegiatan dilakukan oleh siswa dalam periode atau dalam jangka waktu tertentu berdasarkan skala kualifikasi berkatagori cukup. 


\begin{tabular}{|c|c|c|c|c|c|c|}
\hline No & Pertanyaan & $\begin{array}{l}\text { Alternatif } \\
\text { jawaban }\end{array}$ & $\mathrm{N}$ & $\mathrm{F}$ & $\begin{array}{l}\text { Skor } \\
\text { (fxn) }\end{array}$ & $\begin{array}{c}\text { Rata-rata } \\
\sum \frac{f n}{r}\end{array}$ \\
\hline 1. & $\begin{array}{lr}\text { Ketika anda } & \text { kesulitan } \\
\text { dalam } & \text { menghafal } \\
\text { apakah } & \text { anda } \\
\text { melakukannya dengan } \\
\text { cara menghafalnya terus } \\
\text { menerus. }\end{array}$ & $\begin{array}{l}\text { Sering } \\
\text { Kadang - Kadang } \\
\text { Jarang } \\
\text { Tidak pernah }\end{array}$ & $\begin{array}{l}4 \\
3 \\
2 \\
1\end{array}$ & $\begin{array}{l}26 \\
3 \\
3 \\
11\end{array}$ & $\begin{array}{l}104 \\
9 \\
6 \\
11\end{array}$ & 3,02 \\
\hline 2. & $\begin{array}{l}\text { Apakah anda termasuk } \\
\text { siswa yang tekun } \\
\text { didalam melaksanakan } \\
\text { pembelajaran }\end{array}$ & $\begin{array}{l}\text { Sering } \\
\text { Kadang - Kadang } \\
\text { Jarang } \\
\text { Tidak pernah }\end{array}$ & $\begin{array}{l}4 \\
3 \\
2 \\
1\end{array}$ & $\begin{array}{l}10 \\
1 \\
32 \\
0\end{array}$ & $\begin{array}{l}40 \\
3 \\
64 \\
0\end{array}$ & 2,48 \\
\hline \multicolumn{6}{|c|}{ Jumlah rata-rata } & 2,75 \\
\hline
\end{tabular}

Tabel 3.9 Indikator Motivasi belajar PAI mengenai Persistensi

Nilai 2,75 berada di interval 2,50 -3,50 dengan kriteria cukup, ini berarti bahwa ketekunan dalam melakukan kegiatan oleh siswa Madrasah Tsanawiyah Al-Firdaus berdasarkan skala kualifikasi berkatagori cukup.

\begin{tabular}{|c|c|c|c|c|c|c|}
\hline No & Pertanyaan & $\begin{array}{l}\text { Alternatif } \\
\text { jawaban }\end{array}$ & $\mathrm{N}$ & $\mathrm{F}$ & $\begin{array}{l}\text { Skor } \\
(f \times n)\end{array}$ & $\begin{array}{l}\text { Rata-rata } \\
\sum \frac{f n}{r}\end{array}$ \\
\hline \multirow{4}{*}{1.} & Apakah motivasi belajar & Sering & 4 & 12 & 48 & \multirow{4}{*}{2,88} \\
\hline & anda meningkat setelah & Kadang - Kadang & 3 & 14 & 42 & \\
\hline & mengikuti kegiatan & Jarang & 2 & 17 & 34 & \\
\hline & hafalan Al-Qur'an & Tidak pernah & 1 & 0 & 0 & \\
\hline \multirow{4}{*}{2.} & \multirow{4}{*}{$\begin{array}{c}\text { Apakah anda mempunyai } \\
\text { target didalam } \\
\text { menghafal Al-Qur'an }\end{array}$} & Sering & 4 & 43 & 172 & \multirow{4}{*}{4.0} \\
\hline & & Kadang - Kadang & 3 & 0 & 0 & \\
\hline & & Jarang & 2 & 0 & 0 & \\
\hline & & Tidak pernah & 1 & 0 & 0 & \\
\hline \multicolumn{6}{|c|}{ Jumlah rata-rata } & 3,44 \\
\hline
\end{tabular}

Tabel 3. 10 Indikator Motivasi belajar PAI mengenai Tingkat Aspirasinya

Berdasarkan tabel diatas, diperloleh nilai 3,44 berada di interval 2,50 - 3.50 dengan kriteria cukup, ini berarti bahwa cita-cita, sasaran atau target siswa didalam kegiatan hafalan Al-Qur'an berdasarkan skala kualifikasi berkatagori cukup.

\begin{tabular}{|c|c|c|c|c|c|c|}
\hline No & Pertanyaan & Alternatif jawaban & N & F & $\begin{array}{c}\text { Skor } \\
(f \times n)\end{array}$ & $\begin{array}{c}\text { Rata-rata } \\
\sum \frac{f n}{r}\end{array}$ \\
\hline
\end{tabular}




\begin{tabular}{|c|c|c|c|c|c|c|}
\hline 1. & $\begin{array}{l}\text { Apakah anda merasa } \\
\text { beribadah dalam } \\
\text { kegiatan menghafal Al- } \\
\text { Qur'an }\end{array}$ & $\begin{array}{c}\text { Sering } \\
\text { Kadang - Kadang } \\
\text { Jarang } \\
\text { Tidak pernah }\end{array}$ & $\begin{array}{l}4 \\
3 \\
2 \\
1\end{array}$ & $\begin{array}{c}43 \\
0 \\
0 \\
0\end{array}$ & $\begin{array}{c}172 \\
0 \\
0 \\
0\end{array}$ & 4,0 \\
\hline 2. & $\begin{array}{l}\text { Apakah anda tidak } \\
\text { merasa jenuh dalam } \\
\text { menghafal Al-Qur'an. }\end{array}$ & $\begin{array}{c}\text { Sering } \\
\text { Kadang - Kadang } \\
\text { Jarang } \\
\text { Tidak pernah }\end{array}$ & $\begin{array}{l}1 \\
2 \\
3 \\
4\end{array}$ & $\begin{array}{c}0 \\
8 \\
22 \\
13\end{array}$ & $\begin{array}{c}0 \\
16 \\
66 \\
52\end{array}$ & 3,11 \\
\hline \multicolumn{6}{|c|}{ Jumlah rata-rata } & 3,55 \\
\hline
\end{tabular}

Tabel 3. 11 Indikator Motivasi belajar PAI mengenai Sikap terhadap kegiatan

Berdasarkan tabel diatas, diperoleh nilai 3,55 berada di interval 3,50 - 4,50 dengan kriteria tinggi, ini berarti bahwa sikap siswa terhadap kegiatan menghafal AlQur'an berdasarkan skala kualitas berkatagori tinggi.

\begin{tabular}{|c|c|c|c|}
\hline No & Indikator & Skor & Kriteria \\
\hline 1. & Durasi kegiatan & 3.35 & Cukup \\
\hline 2. & Frequensi Kegiatan & 3,36 & Cukup \\
\hline 3. & Persistensi & 2,75 & Cukup \\
\hline 4. & Tingkat Aspirasi & 3,44 & Cukup \\
\hline 5. & Sikap terhadap kegiatan & 3,55 & Tinggi \\
\hline \multicolumn{2}{|r|}{ Jumlah rata-rata } & 3,29 & Cukup \\
\hline
\end{tabular}

Tabel 3. 12

Dari hasil rekapitulasi nilai tentang variabel motivasi siswa belajar Pendidikan Agama Islam jika dirata-ratakan adalah sebagai berikut : $(3,35+3,36+2,75+3,44+$ $3,55)=16,45 / 5=3,29$. Nilai rata-rata 3,29 berada pada interval 2,50 - 3,50 dengan ketentuan kriteria cukup. Hal ini menunjukan motivasi siswa belajar Pendidikan Agama Islam tergolong cukup.

\section{Analisis Pengaruh Hafalan Al-Quran Terhadap Motivasi Belajar siswa dalam mata pelajaran PAI di MTs Al-Firdaus Cipatat}

Untuk mengetahui ada atau tidaknya pengaruh hafalan Al-Quran terhadap motivasi belajar PAI, maka perlu diadakan hipotesis. Adapun hipotesis ini menggunakan pengolahan data dengan regresi sederhana. Adapun langkah-langkah penghitungannya sebagai berikut:

a. Membuat Ha dan Ho dalam bentuk kalimat:

Ho = tidak terdapat pengaruh yang signifikan antara hafalan al-Quran dengan motivasi belajar siswa pada mata pelajaran PAI.

$\mathrm{Ha}=$ Terdapat pengaruh yang signifikan antara hafalan al-Quran dengan motivasi belajar siswa pada mata pelajaran PAI.

b. Membuat tabel penolong untuk menghitung angka statistik 


\begin{tabular}{|c|c|c|c|c|c|}
\hline Responden & $\mathbf{X}$ & $\mathbf{Y}$ & $x^{2}$ & $y^{2}$ & Xy \\
\hline 1 & 88 & 32 & 7744 & 1024 & 2816 \\
\hline 2 & 90 & 33 & 8100 & 1089 & 2970 \\
\hline 3 & 86 & 31 & 7396 & 961 & 2666 \\
\hline 4 & 98 & 29 & 9604 & 841 & 2842 \\
\hline 5 & 95 & 30 & 9025 & 900 & 2850 \\
\hline 6 & 80 & 30 & 6400 & 900 & 2400 \\
\hline 7 & 80 & 32 & 6400 & 1024 & 2560 \\
\hline 8 & 80 & 26 & 6400 & 676 & 2080 \\
\hline 9 & 90 & 34 & 8100 & 1156 & 3060 \\
\hline 10 & 80 & 33 & 6400 & 1089 & 2640 \\
\hline 11 & 90 & 33 & 8100 & 1089 & 2970 \\
\hline 12 & 80 & 29 & 6400 & 841 & 2320 \\
\hline 13 & 90 & 30 & 8100 & 900 & 2700 \\
\hline 14 & 100 & 37 & 10000 & 1369 & 3700 \\
\hline 15 & 90 & 30 & 8100 & 900 & 2700 \\
\hline 16 & 90 & 35 & 8100 & 1225 & 3150 \\
\hline 17 & 90 & 30 & 8100 & 900 & 2700 \\
\hline 18 & 89 & 31 & 7921 & 961 & 2759 \\
\hline 19 & 89 & 35 & 7921 & 1225 & 3115 \\
\hline 20 & 100 & 35 & 10000 & 1225 & 3500 \\
\hline 21 & 89 & 34 & 7921 & 1156 & 3026 \\
\hline 22 & 90 & 35 & 8100 & 1225 & 3150 \\
\hline 23 & 90 & 33 & 8100 & 1089 & 2970 \\
\hline 24 & 89 & 33 & 7921 & 1089 & 2937 \\
\hline 25 & 95 & 31 & 9025 & 961 & 2945 \\
\hline 26 & 80 & 32 & 6400 & 1024 & 2560 \\
\hline 27 & 80 & 29 & 6400 & 841 & 2320 \\
\hline 28 & 95 & 32 & 9025 & 1024 & 3040 \\
\hline 29 & 80 & 29 & 6400 & 841 & 2320 \\
\hline 30 & 80 & 26 & 6400 & 676 & 2080 \\
\hline 31 & 80 & 27 & 6400 & 729 & 2160 \\
\hline 32 & 90 & 30 & 8100 & 900 & 2700 \\
\hline 33 & 95 & 30 & 9025 & 900 & 2850 \\
\hline 34 & 85 & 37 & 7225 & 1369 & 3145 \\
\hline 35 & 85 & 36 & 7225 & 1296 & 3060 \\
\hline 36 & 85 & 27 & 7225 & 729 & 2295 \\
\hline 37 & 85 & 25 & 7225 & 625 & 2125 \\
\hline
\end{tabular}




\begin{tabular}{|c|c|c|c|c|c|}
38 & 75 & 30 & 5625 & 900 & 2250 \\
\hline 39 & 80 & 27 & 6400 & 729 & 2160 \\
\hline 40 & 80 & 34 & 6400 & 1156 & 2720 \\
\hline 41 & 80 & 33 & 6400 & 1089 & 2640 \\
\hline 42 & 89 & 32 & 7921 & 1024 & 2848 \\
\hline 43 & 90 & 32 & 8200 & 1024 & 2880 \\
\hline Jumlah & 3742 & 1349 & 327374 & 42691 & 117679 \\
\hline
\end{tabular}

Tabel 3.1 Pengaruh Hafalan Al-Quran terhadap Motivasi belajar siswa

c. Masukkan angka-angka statistik dari tabel penolong dengan rumus:

1. Menghitung rumus $b$ :

$$
\begin{aligned}
& b=\frac{n \sum x y-\left(\sum x\right)\left(\sum y\right)}{\left(n \sum x^{2}\right)-\left(\sum x\right)^{2}}=\cdots \\
& b=\frac{43 \times 117679-(3742)(1349)}{(43 \times 327374)-(3742)^{2}}=\cdots \\
& b=\frac{5.060 .169-5.049 .968}{(14.072 .782)-14002564}=\cdots \\
& b=\frac{12.239}{70.218}=0,17
\end{aligned}
$$

2. Menghitung rumus a:

$$
\begin{aligned}
& a=\frac{\sum y-b\left(\sum x\right)}{n}=\cdots \\
& a=\frac{3137 \cdot 5-(-3,84) \cdot 3742}{43}=\cdots \\
& a=\frac{17357,1}{43}=403,65
\end{aligned}
$$

3. Menghitung regresi sederhana:

$$
\begin{aligned}
& y^{\prime}=a+b x \\
& =403.65+0,17 \mathrm{x}
\end{aligned}
$$

Jadi ada hubungan positif antara hafalan Al-Quran dengan motivasi belajar siswa pada mata pelajaran Pendidikan Agama Islam.

4. Analisis korelasi

$$
r=\frac{\sum x y-\frac{\left(\sum x\right)\left(\sum y\right)}{n}}{\sqrt{\left(\sum x^{2}\right)-\frac{\left(\sum x\right)^{2}}{n} x \sum y^{2}-\frac{\left(\sum y\right)^{2}}{n}}}=\cdots
$$




$$
\begin{aligned}
& r=\frac{117679-\frac{(3742)(1349)}{43}}{\sqrt{\left.(327374)-\frac{(3742)^{2}}{43}\right) x\left(42691-\frac{(1349)^{2}}{43}\right.}}=\cdots \\
& r=\frac{284,6279}{\sqrt{1.632,9767 \times 370,04651}}=\cdots \\
& r=\frac{284,6279}{\sqrt{604.277,3287}}=\cdots \\
& r=\frac{284,6279}{777,3527698}=0,37
\end{aligned}
$$

5. Menghitung determinasi

$$
\begin{aligned}
& D=r^{2} \times 100 \% \\
& D=0,37^{2} \times 100 \% \\
& D=13,69 \%
\end{aligned}
$$

Jadi dapat diketahui bahwa pengaruh hafalan Al-Quran terhadap motivasi belajar siswa Mts Al-Firdaus Cipatat - Bandung Barat pada mata pelajaran Pendidikan Agama Islam sebesar $13,69 \%$, dan sisanya $86,31 \%$ dipengaruhi oleh faktor lain.

\section{Analisis Hafalan Al-Qur'an di Madrasah Al-Firdaus Cipatat Bandung}

Jumlah nilai keseluruhan bidang studi hafalan Al-Quran siswa/siswi MTs Al-Firdaus Cipatat Bandung Barat adalah 3742. Setelah jumlah nilai 3742 dibagi dengan jumlah responden yang berjumlah 43 orang, maka nilai rata-rata siswa/siswi MTs Al-Firdaus Cipatat-Bandung Barat dalam bidang studi hafalan Al-Quran adalah 87,02. Dengan demikian, nilai rata-rata prestasi belajar siswa dalam bidang studi hafalan Al-Quran di MTs Al-Firdaus Cipatat-Bandung Barat adalah baik sekali. Hal itu bila dikaitkan dengan Kriteria Ketuntasan Minimal (KKM) pada mata pelajaran hafalan Al-Quran adalah 70, maka semua siswa dapat dikatakan telah memenuhi kriteria ketuntasan minimal.

\section{Analisis Motivasi Belajar Siswa (variabel Y)}

1) Motivasi belajar PAI mengenai durasi kegiatan

Nilai 3,35 berada di interval 2,50 - 3,50 dengan kriteria cukup, ini berarti kemampuan menggunakan waktu untuk melakukan kegitan hafalan Al-Qur'an oleh siswa madrasah Tsanawiyah Al-Firdaus berdasarkan skala kualifikasi berkatagori cukup.

2) Motivasi belajar PAI mengenai Frequensi Kegiatan

Nilai 3,35 berada di interval 2,50 -3,50 dengan kriteria cukup, ini berarti kemampuan berapa seringnya kegiatan dilakukan oleh siswa dalam periode atau dalam jangka waktu tertentu berdasarkan skala kualifikasi berkatagori cukup.

3) Motivasi belajar PAI mengenai Persistensi 
Nilai 2,75 berada di interval 2,50 -3,50 dengan kriteria cukup, ini berarti bahwa ketekunan dalam melakukan kegiatan oleh siswa Madrasah Tsanawiyah AlFirdaus berdasarkan skala kualifikasi berkatagori cukup.

4) Motivasi belajar PAI mengenai Tingkat Aspirasinya

Berdasarkan tabel diatas, diperloleh nilai 3,44 berada di interval 2,50 - 3.50 dengan kriteria cukup, ini berarti bahwa cita-cita, sasaran atau target siswa didalam kegiatan hafalan Al-Qur'an berdasarkan skala kualifikasi berkatagori cukup.

5) Motivasi belajar PAI mengenai Sikap terhadap kegiatan

Berdasarkan tabel diatas, diperoleh nilai 3,55 berada di interval 3,50 - 4,50 dengan kriteria tinggi, ini berarti bahwa sikap siswa terhadap kegiatan menghafal Al-Qur'an berdasarkan skala kualitas berkatagori tinggi.

\begin{tabular}{|c|c|c|c|}
\hline No & Indikator & Skor & Kriteria \\
\hline 1. & Durasi kegiatan & 3.35 & Cukup \\
\hline 2. & Frequensi Kegiatan & 3,36 & Cukup \\
\hline 3. & Persistensi & 2,75 & Cukup \\
\hline 4. & Tingkat Aspirasi & 3,44 & Cukup \\
\hline 5. & Sikap terhadap kegiatan & 3,55 & Tinggi \\
\hline \multicolumn{2}{r|}{ Jumlah rata-rata } & 3,29 & Cukup \\
\hline
\end{tabular}

Tabel 3. 12 Rekapitulasi Nilai Tentang Variabel

Motivasi Siswa Belajar Pendidikan Agama Islam

Dari hasil rekapitulasi nilai tentang variabel motivasi siswa belajar Pendidikan Agama Islam jika dirata-ratakan adalah sebagai berikut : $(3,35+3,36+2,75+3,44+$ $3,55)=16,45 / 5=3,29$. Nilai rata-rata 3,29 berada pada interval 2,50 - 3,50 dengan ketentuan kriteria cukup. Hal ini menunjukan motivasi siswa belajar Pendidikan Agama Islam tergolong cukup.

\section{Analisis Pengaruh Hafalan Al-Quran Terhadap Motivasi Belajar siswa dalam mata pelajaran PAI di MTs Al-Firdaus Cipatat}

Analisis korelasi hafalan Al-Quran terhadap motivasi belajar siswa Mts Al-Firdaus Cipatat - Bandung Barat pada mata pelajaran Pendidikan Agama Islam, sebagai berikut

$$
\begin{aligned}
& r=\frac{\sum x y-\frac{\left(\sum x\right)\left(\sum y\right)}{n}}{\sqrt{\left(\sum x^{2}\right)-\frac{\left(\sum x\right)^{2}}{n} x \sum y^{2}-\frac{\left(\sum y\right)^{2}}{n}}}=\cdots \\
& r=\frac{117679-\frac{(3742)(1349)}{43}}{\sqrt{\left.(327374)-\frac{(3742)^{2}}{43}\right) x\left(42691-\frac{(1349)^{2}}{43}\right.}}=\cdots
\end{aligned}
$$




$$
\begin{aligned}
& r=\frac{284,6279}{\sqrt{1.632,9767 \times 370,04651}}=\cdots \\
& r=\frac{284,6279}{\sqrt{604.277,3287}}=\cdots \\
& r=\frac{284,6279}{777,3527698}=0,37
\end{aligned}
$$

Menghitung determinasi

$$
\begin{aligned}
& D=r^{2} \times 100 \% \\
& D=0,37^{2} \times 100 \% \\
& D=13,69 \%
\end{aligned}
$$

Jadi dapat diketahui bahwa pengaruh hafalan Al-Quran terhadap motivasi belajar siswa Mts Al-Firdaus Cipatat - Bandung Barat pada mata pelajaran Pendidikan Agama Islam sebesar $13,69 \%$, dan sisanya $86,31 \%$ dipengaruhi oleh faktor lain.

\section{Kesimpulan}

Jumlah nilai keseluruhan bidang studi hafalan Al-Quran siswa/siswi MTs AlFirdaus Cipatat-Bandung Barat adalah 3742. Setelah jumlah nilai 3742 dibagi dengan jumlah responden yang berjumlah 43 orang, maka nilai rata-rata siswa/siswi MTs AlFirdaus Cipatat-Bandung Barat dalam bidang studi hafalan Al-Quran adalah 87,02. Dengan demikian, nilai rata-rata prestasi belajar siswa dalam bidang studi hafalan AlQuran di MTs Al-Firdaus Cipatat-Bandung Barat adalah baik sekali. Hal itu bila dikaitkan dengan Kriteria Ketuntasan Minimal (KKM) pada mata pelajaran hafalan Al-Quran adalah 70, maka semua siswa dapat dikatakan telah memenuhi kriteria ketuntasan minimal.

Realitas motivasi belajar siswa pada mata pelajaran Pendidikan Agama Islam menunjukkan kwalifikasi cukup. Hal ini ditunjukkan oleh hasil rata perhitungan statistik mencapai 3,29 dan angka tersebut berada pad interval 2,50-3,50.

Setelah berdasarkan hasil analisis data, maka dapat disimpulkan bahwa pengaruh hafalan Al-Quran terhadap motivasi belajar siswa Mts Al-Firdaus Cipatat - Bandung Barat pada mata pelajaran Pendidikan Agama Islam sebesar 13,69 \%, dan sisanya 86,31 $\%$ dipengaruhi oleh faktor lain. 
Linda Siti Nurhayati dan Rifqi Fauzan Sholeh

\section{Bibliografi}

A.M,Sardiman. (2005). Interaksi dan motivasibelajarmengajar. Raja Grafindo Persada. Jakarta

Surahmad, Winarno. (1994). Pengantar Penelitian Ilmiah. Tarsito. Bandung.

Ali, Muhamad. (1996). Penelitian Pendidikan Prosedur dan Strategi. Aksara. Bandung. Witherington. (1983). Psikologi pendidikan (Alih Bahasa: M. Bukhori). Aksara Baru. Jakarta.

Arikunto, Suharsimi. (2002). Penelitian Prosedur. Rineka Cipta. Jakarta.

Abdul Majid Khon. (2008). Praktikum Qira'at. Amzah. Jakarta.

Prof. DR, Sugiono. (2012). Metode Penelitian Pendidikan. Alfabeta. Bandung. 